\title{
Zatrudnianie cudzoziemców z krajów trzecich z perspektywy prawa krajowego i realiów rynku pracy - panorama zjawiska
}

\section{Employment of foreigners from third countries from the perspective of national law and labour market realities - panorama of the phenomenon}

\author{
dr Izabela Florczak
}

Uniwersytet Łódzki, Katedra Prawa Pracy, Zakład Prawa Ubezpieczeń Społecznych i Polityki Społecznej, Polska Sieć Naukowa Prawa Pracy i Zabezpieczenia Społecznego COOPERANTE

iflorczak@wpia.uni.lodz.pl

ORCID: 0000-0003-3167-3382

\begin{abstract}
Streszczenie W ostatnich latach wzrasta w Polsce skala zatrudnienia cudzoziemców z krajów trzecich, tj. takich, którzy nie są obywatelami państw członkowskich Unii Europejskiej, państw członkowskich Europejskiego Stowarzyszenia Wolnego Handlu (EFTA) - strony umowy o Europejskim Obszarze Gospodarczym lub Konfederacji Szwajcarskiej. Prognozy jednoznacznie potwierdzają, że trend ten będzie się wzmagał. Świadczy to o potrzebie korzystania polskiej gospodarki z zewnętrznych zasobów osób zatrudnionych. Proces zatrudniania cudzoziemców z krajów trzecich związany jest z trzema płaszczyznami: uzyskiwania przez nich właściwych zezwoleń, warunków wykonywania pracy oraz włączania ich w zasoby osób aktywnych zawodowo. Istniejące w tym zakresie regulacje prawne trudno uznać za systemowe i wewnętrznie spójne, co w konsekwencji może powodować spowolnienie rozwoju gospodarczego. Celem artykułu jest zasygnalizowanie najistotniejszych problemów związanych z zatrudnianiem obywateli państw trzecich, wynikających zarówno z realiów prawnych jak i faktycznej sytuacji na rynku pracy, stanowiąc tym samym przyczynek do dalszej, jakże koniecznej, dyskusji nad tą problematyką.
\end{abstract}

Słowa kluczowe: cudzoziemcy, rynek pracy, kraje trzecie.

Summary The scale of the employment of foreigners from third countries is increasing. Forecasts clearly confirm that this trend will increase. This illustrates the need of the Polish economy to use the external resources of workers. The process of employing foreigners from third countries is connected with three areas. Obtaining appropriate permits, working conditions and including them in the resources of people active on the labour market. The existing legal regulations in this area cannot be considered as systemic and internally consistent, which in may cause a slowdown in economic development. This text aims to signal the most significant problems related to the employment of third-country nationals resulting both from legal realities and the actual situation on the labour market, making a contribution to further, necessary, discussion of these issues.

Keywords: foreigners, labour market, third countries.

Str. 2-5 


\section{Bibliografia}

Eurostat. (2018). Residence permits for non-EU citizens. First residence permits issued in the EU Member States remain above 3 million in 2017, https://ec.europa.eu/eurostat/documents/2995521/-9333446/3-25102018-AP-EN.pdf/3fa5fa53-e076-4a5f-8bb5-a8075f639167 (27.10.2018).

Florczak, I. (2018). Terminowe zatrudnianie cudzoziemców w prawie polskim. W: A. Musiała (red.), Nauka i praktyka w stużbie człowiekowi pracy: Umowy terminowe. Poznań.

Gazeta Prawna. (2018). Ambasada w New Delhi nie nadąża z wystawianiem wiz. Hindusi, Nepalczycy i Banglijczycy chca pracować w Polsce, https://serwisy.gazetaprawna.pl/praca-i-kariera/artykuly/1251844,praca-hindusow-w-polsce-ambasada-w-new-delhi-wystawiawizy-zbytwolno.html (02.12.2018).

Główny Urząd Statystyczny. (2018). Rocznik Statystyczny Rzeczpospolitej Polskiej 2017, https://stat.gov.pl/obszary-tematyczne/rocznikistatystyczne/roczniki-statystyczne/rocznik-statystyczny-rzeczypospolitej-polskiej-2017,2,17.html (02.12.2018).

Godlewska-Bujok, B. (2018). O kształtowaniu prawa pracy i jego związkach z polityką społeczną. Studia z Zakresu Prawa Pracy i Polityki Spolecznej, 25(4).

IZA. (2018). Germany's Immigration Policy and Labor Shortages Amelie F. Constant Bienvenue N. Tien, http://ftp.iza.org/report_pdfs/iza_report_41.pdf (02.12.2018).

Kaczmarczyk, P. (2008). Współczesne migracje z Polski — próba statystycznej oceny zjawiska. W: P. Kaczmarczyk (red.), Wspótczesne migracje zagraniczne Polaków. Aspekty lokalne i regionalne. Warszawa.

McKay, S. (2009). The commonalities of Experience: Refugees and Recent Migrants. W: S. McKay (red.), Refugees, Recent Migrants and Employment. Challenging Barriers and ExploringPathways.

Ministerstwo Rodziny, Pracy i Polityki Społecznej. (2018a). Bezrobocie rejestrowane w Polsce. Raport miesięczny - wrzesień 2018 r., https://archiwum.mpips.gov.pl/analizy-i-raporty/bezrobocie-rejestrowane-wpolsce/rok-2018/ (02.12.2018).

Ministerstwo Rodziny, Pracy i Polityki Społecznej. (2018b). Nowe kierunki imigracji zarobkowej do Polski, https://archiwum.mpips.gov.pl/aktualnosci-wszystkie/art,5543,10121,nowe-kierunki-imigracji-zarobkowej-dopolski.html (03.12.2018)

Ministerstwo Rodziny, Pracy i Polityki Społecznej. (2018c). Raporty roczne MRPiPS, https://archiwum.mpips.gov.pl/analizy-iraporty/cudzoziemcy-pracujacy-w-polsce-statystyki/ (18.11.2018).

Ministerstwo Rodziny, Pracy i Polityki Społecznej (2018d). Statystyka - zezwolenie na pracę sezonową, http://psz.praca.gov.pl/web/urzad-pracy//8180228-zezwolenia-na-prace-sezonowa-cudzoziemca (18.11.2018).

Ministerstwo Rodziny, Pracy i Polityki Społecznej. (2018e). Zatrudnianie cudzoziemców VII 2018 r., http://psz.praca.gov.pl/web/urzadpracy/8180234-informacje-o-zatrudnieniu-cudzoziemcow-w-polsce (18.11.2018).

Ministerstwo Rodziny, Pracy i Polityki Społecznej (2018f). Zawody deficytowe. Informacja sygnalna na temat zawodów deficytowych, zrównoważonych $i$ nadwyzkowych w I pótroczu 2018 roku, https://archiwum.mpips.gov.pl/analizy-i-raporty/raportysprawozdania/rynek-pracy/zawody-deficytowe-i-nadwyzkowe/rok-2018/ (02.12.2018).

Mitrus, L. (2018). Zatrudnienie cudzoziemców w Polsce. W: M. Włodarczyk (red.), System prawa rynku pracy. Tom VIII. Prawo rynku pracy. Warszawa.

Work Servis. (2018). Postawy obywateli Ukrainy wobec polskiego rynku pracy, http://www.porp.pl/g2/2018_09/01e6f0fc7e010cf3518fc7d31b673836.pdf (02.12.2018). 